\title{
PENGARUH KUALITAS PELAYANAN TERHADAP LOYALITAS PELANGGAN DENGAN KEPUASAN SEBAGAI VARIABEL INTERVENING (Studi Persepsi Pada Pelanggan Dian Comp Ambarawa)
}

Oleh :

\author{
Yulia Larasati Putri \\ Alumni STIE AMA Salatiga \\ Hardi Utomo \\ Dosen Tetap STIE AMA Salatiga
}

\begin{abstract}
Abstrak
Tujuan penelitian ini adalah untuk mengetahui pengaruh signifikan kualitas pelayanan terhadap loyalitas pelanggan, pengaruh signifikan kualitas pelayanan terhadap kepuasan pelanggan, pengaruh signifikan kepuasan pelanggan terhadap loyalitas pelanggan, serta pengaruh kualitas pelayanan terhadap loyalitas pelanggan dengan kepuasan pelanggan sebagai variabel intervening.

Penelitian ini merupakan penelitian explanatory dengan jumlah sampel sebanyak 95 responden. Data yang digunakan adalah data primer. Pemilihan sampel dalam penelitian ini menggunakan Berdasarkan hasil path analysis untuk mengetahui pengaruh signifikan kualitas pelayanan terhadap loyalitas pelanggan, didapatkan kesimpulan bahwa kualitas pelayanan berpengaruh positif terhadap loyalitas pelanggan secara signifikan pada tingkat signifikansi $(p<0.05)$. Dari hasil perhitungan statistik diperoleh bahwa thitung > t tabel yaitu 7,260 > 1,986. Hal ini mengindikasikan bahwa kualitas pelayanan yang dinilai baik di mata konsumen dapat mempengaruhi terbentuknya loyalitas konsumen terhadap suatu produk atau jasa, Nilai adjusted $R^{2}$ sebesar 0,355; artinya bahwa 35,5\% variabel endogen (Loyalitas Pelanggan) dapat dijelaskan oleh variabel eksogennya (Kualitas Pelayanan). Sisanya sebesar 64,5\% dipengaruhi oleh variabel lain yang tidak diikutsertakan dalam penelitian ini maka didapatkan kesimpulan bahwa kualitas pelayanan berpengaruh positif terhadap loyalitas pelanggan secara signifikan pada tingkat signifikansi $(p<0.01)$. Hal ini mengindikasikan bahwa Konsumen yang merasa puas dengan suatu produk atau jasa tertentu, cenderung memiliki potensi yang besar untuk menjadi loyal terhadap produk atau jasa tersebut.

Dalam pengujian pengaruh langsung dan tidak langsung, kualitas pelayanan secara signifikan berpengaruh langsung terhadap loyalitas pelanggan. Hal ini terbukti dari Nilai pengaruh antara kualitas pelayanan terhadap loyalitas pelanggan > dari pengaruh tidak langsungnya, yaitu 0,601 > 0,519. Jadi kepuasan bukan merupakan variabel intervening pada penelitian ini. untuk itu, pada penelitian selanjutnya bisa meneliti variabel lain seperti kepercayaan untuk mengetahui faktor yang lebih berpengaruh sebagai variabel intervening terhadap loyalitas pelanggan.
\end{abstract}

\section{Kata Kunci : Kualitas Pelayanan, Kepuasan, Loyalitas Pelangga}




\section{PENDAHULUAN}

Dalam era perdagangan bebas setiap perusahaan menghadapi persaingan yang ketat. Bukan hanya perusahaan yang sudah bertaraf internasional dan go public saja tetapi usaha kecil menengah pun juga mengalami persaingan. Meningkatnya intensitas persaingan dan jumlah pesaing menuntut perusahana untuk selalu memperhatikan kebutuhan dan keinginan pelanggan serta berusaha memenuhi harapan pelanggan dengan cara memberikan pelayanan yang lebih memuaskan daripada yang dilakukan oleh pesaing. Kualitas pelayanan sangat penting dalam menjalankan sebuah bisnis. Selain menawarkan berbagai macam produk, perbaikan di sisi teknologi informasi, pelayanan fisik, dan pelayanan non fisik dimaksudkan untuk meningkatkan kualitas pelayanan (Ariyani, 2008). Terlebih lagi pada perusahan yang bergerak di bidang jasa yang produknya yang tidak berwujud. Oleh karena itu, kepuasaan konsumenlah merupakan salah satu tolak ukur dari kualitas pelayanan yang diberikan.

Untuk memenuhi kepuasan konsumen pada industri jasa, kualitas pelayanan sangat penting bagi perusahaan untuk dikelola dengan baik. Kualitas pelayanan merupakan tingkat keunggulan untuk memenuhi keinginan konsumen. Kualitas pelayanan yang baik dimulai dari persepsi konsumen, bukan dari perusahaan. Menurut Bedi (2010) memberikan layanan yang berkualitas tinggi adalah suatu keharusan untuk mencapai kepuasan pelanggan. Bagi pelanggan, kualitas pelayanan dan kepuasan pelanggan berasal dari layanan yang terorganisir, dengan begitu akan menciptakan persepsi yang baik pada pelanggan. Persepsi konsumen terhadap kualitas pelayanan, merupakan penilaian total atas keunggulan suatu produk yang dapat berupa barang atau jasa.

Keberhasilan suatu perusahaan jasa ditentukan oleh kemampuan perusahaan tersebut dalam membangun loyalitas pelanggan. Menurut Partua Pramana (2014) loyalitas pelanggan merupakan akibat dari suatu percobaan awal sebuah produk yang diperkuat melalui kepuasan sehingga akan mengarah pada pembelian ulang. Pembelian ulang oleh konsumen tentu saja akan meningkatkan volume penjualan yang berarti akan meningkatkan laba perusahaan. Loyalitas tersebut akan menjadi salah satu tujuan yang harus dicapai oleh suatu perusahaan dalam mempertahankan pelanggannya dari serbuan perusahaan pesaing sejenis. Dengan berhasilnya membangun loyalitas pelanggan, kelangsungan hidup perusahaan akan tetap bertahan pada kondisi perekonomian yang sedang mengalami ketidakpastian seperti saat ini.

Dian Computer merupakan salah satu usaha yang bergerak dibidang jasa yang meliputi jasa service (komputer dan printer), rental ketik cetak, penjualan (komputer, 
printer, sparepart, dan asessories) dan kursus komputer yang beralamatkan di Jl. Pandean No. 82 Kelurahan Lodoyong Kecamatan Ambarawa. Dian Computer berdiri sejak tahun 1996 dan masih eksis sampai sekarang meskipun banyak usaha sejenis mulai bermunculan yang otomatis menjadi pesaing. Berikut data pelanggan Dian Comp 10 bulan terakhir tahun 2016 :

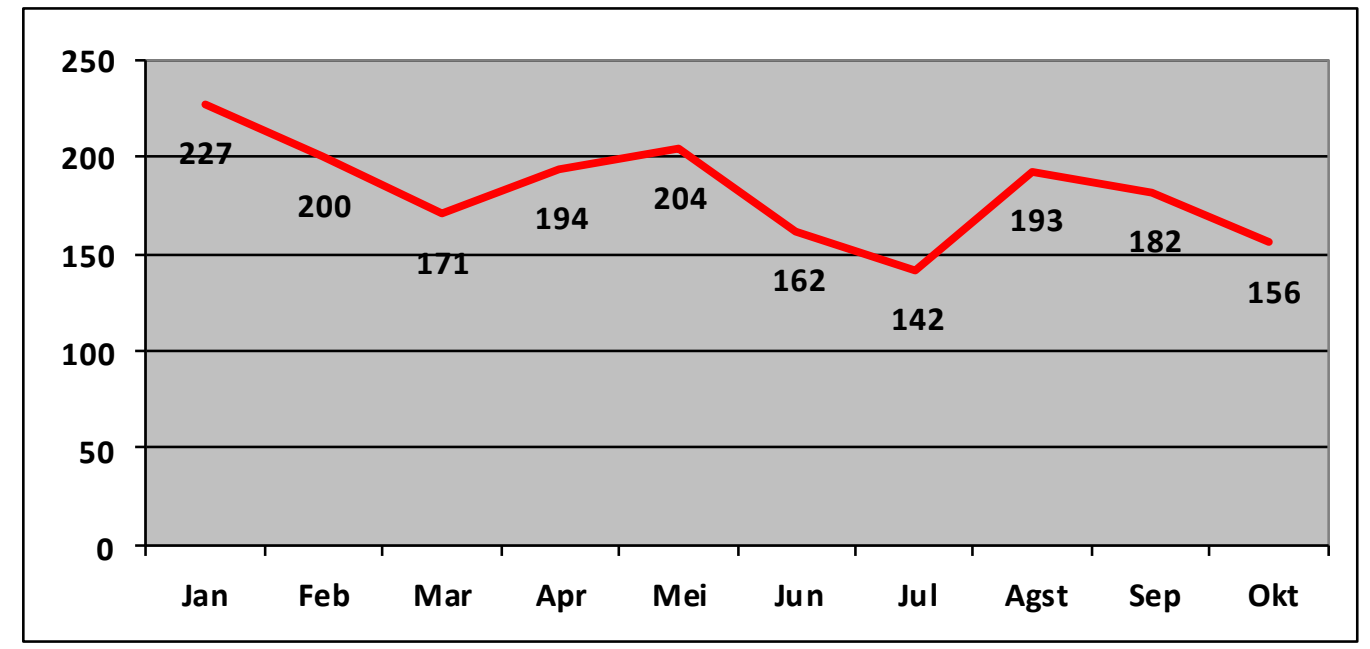

Sumber laporan keuangan 10 bulan terakhir

Gambar 1

Data Pelanggan Dian Comp 10 bulan terakhir

Berdasarkan grafik diatas dapat dilihat bahwa tiga bulan terakhir ini antara bulan Agustus sampai Oktober tahun 2016 pelanggan Dian Comp mengalami penurunan. Hal ini bisa saja dikarenakan semakin banyaknya pesaing di sekitar Kelurahan Panjang dan Lodoyong. Berikut data pesaing Dian Comp di Kelurahan Kranggan, Panjang dan Lodoyong. Dengan kondisi persaingan yang sangat kompetitif ini perusahaan jasa seperti Dian Comp seharusnya mulai menyadari betapa pentingnya peran pelanggan. Kiki Egga (2010) mengatakan bahwa unsur-unsur yang membentuk loyalitas pelanggan merupakan suatu pelayanan yang berkualitas dimana perpaduan dari kualitas manusia yang dicerminkan oleh perilaku atau sikap pribadi dalam berinteraksi dengan para pelanggan. Pelangganlah yang menjadi salah satu sumber dari keberlangsungnya perusahaan.

Oleh karena itu, banyak perusahaan mempertahankan pasarnya melalui program pengembangan loyalitas pelanggan melalui kepuasan pelanggan sebagai standar penilaian. Perusahaan jasa sudah semestinya menjaga kualitas pelayanan sebagai rancangan strategi yang tepat dalam mencapai tujuan mempertahankan loyalitas pelanggan dan membuat pelanggan selalu merasa puas sehingga tetap setia terutama karena produk jasanya yang tak berwujud (intangible). 
Berdasarkan observasi dan wawancara yang dilakukan, dari beberapa pelanggan Dian Comp mengatakan bahwa kualitas pelayanan di Dian sudah bagus. Sebagian besar merasa puas, karena hasil yang diperoleh sesuai dengan harapan dari pelanggan, tetapi itu baru merupakan opini dan persepsi dari pelanggan yang telah menggunakan jasa Dian Comp.

\section{Permasalahan Penelitian}

Berdasarkan latar belakang di atas, maka dapat dirumuskan masalah sebagai berikut :

1. Apakah ada pengaruh kualitas pelayanan terhadap loyalitas pelanggan di Dian Comp Ambarawa?

2. Apakah ada pengaruh kualitas pelayanan terhadap kepuasan pelanggan di Dian Comp Ambarawa?

3. Apakah ada pengaruh kepuasan pelanggan terhadap loyalitas pelanggan di Dian Comp Ambarawa?

4. Apakah ada pengaruh kualitas pelayanan terhadap loyalitas pelanggan dengan kepuasaan pelanggan sebagai variabel intervening pada pelanggan Dian Comp Ambarawa?

\section{Tujuan dan Manfaat Penelitian}

Tujuan dari penelitian ini adalah :

a. Untuk mengetahui pengaruh kualitas pelayanan terhadap loyalitas pelanggan Dian Comp Ambarawa.

b. Untuk mengetahui pengaruh kualitas pelayanan terhadap kepuasaan pelanggan Dian Comp Ambarawa.

c. Untuk mengetahui pengaruh kepuasaan pelanggan terhadap loyalitas pelanggan Dian Comp Ambarawa.

d. Untuk mengetahui pengaruh kualitas pelayanan terhadap loyalitas pelanggan dengan kepuasaan pelanggan sebagai variabel intervening pada pelanggan Dian Comp Ambarawa.

Penelitian ini diharapkan dapat memberikan manfaat bagi peneliti, pelaku bisnis sejenis dan STIE AMA Salatiga sebagai bahan wawasan dan pengetahuan untuk pengambilan keputusan berikutnya.

\section{LANDASAN TEORI}

\section{Kualitas Pelayanan}

Kualitas pelayanan merupakan salah satu elemen penting yang menjadi pertimbangan bagi pelanggan dalam melakukan pembelian suatu produk. Menurut Parasuraman, Zeithmal dan Berry yang dikutip oleh Sudarso (2012 : 57), Kualitas 
Pelayanan merupakan penilaian atau sika global berkenaan dengan superioritas suatu pelayanan. Defiini ini didasarkan pada 3 landasan konseptual utama, yaitu (1) kualiats pelayanan lebih sulit dievaluasi pelanggan dibandingkan dengan kualitas barang, (2) persepsi terhadap kualitas pelayanan merupakan hasil perbandingan antara harapan pelanggan dengan kinerja aktual pelayanan, (3) evaluasi kualitas pelayanan tidak hanya dilakukan atas hasil pelayanan, namun juga mencakup evaluasi terhdap proses penyampaian pelayanan.

Menurut Tjiptono dan Chandara (2011:172), kualitas pelayanan berkaitan erat dengan kepuasaan pelanggan. Kualitas pelayanan memberikan dorongan khusus bagi para pelangga untuk menjalin ikatan relasi saling menguntungkan dalam jangka panjang dengan perusahaan.

Sedangkan menurut Lovelock (2013), Kualitas Pelayanan adalah tingkat keunggulan yang diharapkan dan pengendalian atas tingkat keunggulan tersebut untuk memenuhi keinginan pelanggan. Pendapat lain dikemukan oleh Sunyoto (2012:236) bahwa kualitas pelayanan merupakan suatu ukuran untuk menilai bahwa suatu barang atau jasa telah mempunyai nilai guna seperti yang dikendaki atau dengan kata lain suatu barang atau jasa dianggap telah memiliki mutu apabila berfungsi atau mempunyai nilai guna seperti yang diinginkan.

Jadi dapat disimpulkan bahwa Kualitas Pelayanan merupakan suatu penyajian produk atau jasa yang sesuai dengan standar perusahaan dan diupayakan dalam penyampaian produk dan jasa tersebut sama dengan apa yang diharapkan pelanggan atau melebihi harapannya.

Untuk meningkatkan kualitas pelayanan suatu perusahaan ada banyak faktor yang harus dipertimbangkan (Sunyoto, 2012:241), diantaranya :

a. Mengidentifikasi Determinasi Utama Kualitas Jasa

Setiap perusahaan jasa perlu berupaya memberikan kualitas yang terbaik kepada pelanggannya. Oleh karena itu langkah pertama yang dilakukan adalah mengadakan riset untuk mengindentifikasikan determinasi jasa yang paling penting bagi pasar sasaran. Langkah berikutnya adalah memperkirakan penilaian yang diberikan pasar sasaran terhadap perusahaan dan pesaing berdasarkan determinasi-determinasi tersebut.

b. Mengelola Harapan Pelanggan

Tidak jarang suatu perusahaan berusahan melebih-lebihkan pesan komunikasinya kepada pelanggan dengan maksud agar mereka terpikat. Untuk itu ada satu hal yang dapat dijadikan pedoman yaitu: "Jangan janjikan apa yang tidak bisa diberikan, tetapi berikan lebih dari yang dijanjikan". 
c. Mengelola Bukti Kualitas Jasa

Pengelolaan bukti kualitas jasa bertujuan untuk memperkuat persepsi pelanggan selam dan sesudah jasa diberikan. Oleh karena itu jasa merupakan kinerja dan tidak dapat dirasakan sebagaiman halnya barang, maka pelanggan cenderung memperhatikan fakta-fakta bukti langsung yang berkaitan dengan jasa sebagai bukti kualitas

d. Harapan Pelanggan

Umumnya faktor-faktor yang menentukan harapan pelanggan meliputi: kebutuhan pribadi, pengalaman masa lampau, rekomendasi dari mulut ke mulut dan iklan.

\section{Kepuasan Pelanggan}

Kepuasan dapat didefinisikan sebagai perasaan senang atau kecewa seseorang dari membandingkan kinerja produk yang dirasakan dalam hubungan dan harapannya. Menurut Menurut Zikmund, McLeod dan Gilbert (2003:72), kepuasan adalah sebagai evaluasi setelah pembelian hasil dari perbandingan antara harapan sebelum pembelian dengan kinerja sesungguhnya. Sedangkan menurut Kotler (2001:21), kepuasan merupakan fungsi dari kinerja yang dirasakan (perceived performance) dan harapan (expectations). Jika kinerja produk atau jasa lebih rendah dari harapan, konsumen akan merasa tidak puas. Jika kinerja sesuai harapan maka konsumen akan merasa puas, jika kinerja sampai melebihi harapan, maka konsumen akan merasa sangat puas (delighted).

Pada dasarnya setiap perusahaan yang melakukan program kualitas pelayanan maka akan menciptakan kepuasan pelanggan. Pelanggan yang memperoleh kepuasan dalam pelayanan merupakan modal dasar bagi perusahaan dalam membentuk loyalitas pelanggan.

Menurut Tjiptono (2007:348) setiap perusahaan yang memperhatikan kepuasan pelanggan akan memperoleh beberapa manfaat pokok yaitu reputasi perusahaan yang makin positif dimata pelanggan dan masyarakat, serta dapat mendorong terciptanya loyalitas pelanggan yang memungkinkan bagi perusahaan, meningkatkan keuntungan, harmonisnya hubungan perusahaan dengan pelanggannya, serta mendorong setiap orang dalam perusahaan untuk bekerja dengan tujuan yang lebih baik.

Secara sederhana kepuasan diartikan sebagai 'upaya pemenuhan sesuatu atau membuat sesuatu memadai (Tjiptono, 2007:349). Howard dan Sheth dalam Tjiptono (2007:349) mengungkapkan bahwa kepuasan pelanggan adalah situasi kognitif pembeli yang berkenaan dengan kesepadanan atau 
ketidaksepadanan antara hasil yang didapatkan dengan pengorbanan yang dilakukan.

Pelanggan mengalami berbagai tingkat kepuasan dan ketidakpuasan setelah mengalami atau merasakan masing-masing jasa sesuai dengan sejauh mana harapan mereka terpenuhi atau terlampaui. Harapan adalah standar internal yang digunakan pelanggan untuk menilai kualitas suatu pengalaman jasa (Lovelock dan Wright, 2007:93). Sebuah perusahaan harus menjaga kualitas jasa yang ditawarkan kepada pelanggan. Apabila kualitas jasa yang diterima oleh pelanggan lebih baik atau sama dengan yang dibayangkan, maka pelanggan cenderung akan mencoba kembali. Akan tetapi, apabila perceived services lebih rendah dari expected services maka pelanggan akan kecewa yang mengakibatkan konsumen berhenti berhubungan dengan perusahaan yang bersangkutan (Alma, 2005:282).

Penyebab timbulnya rasa tidak puas pelanggan terhadap pelayanan dapat disebabkan oleh bebarapa hal yaitu (Alma, 2005:286) :

a. Ketidaksesuaian harapan dengan kenyataan.

b. Layanan selama proses penyampaian jasa tidak memuaskaan.

c. Perilaku personil kurang memuaskan

d. Suasana dan kondisi fisik tidak menunjang

e. Biaya terlalu tinggi, jarak terlalu jauh sehingga banyak waktu terbuang

f. Promosi atau iklan terlalu berlebihan dan tidak sesuai dengan kenyataan yang ada

\section{Loyalitas Pelanggan}

Loyalitas merupakan kondisi psikologis yang berkaitan dengan sikap terhadap produk, konsumen akan membentuk keyakinan, menetapkan suka dan tidak suka, dan memutuskan apakah mereka ingin membeli produk (Hasan, 2014:134). Loyalitas konsumen merupakan perilaku yang terkait dengan merek sebuah produk, termasuk kemungkinan memperbaharui kontrak merek dimasa yang akan datang, berapa kemungkinan pelanggan mengubah dukungannya terhadap merk, berapa kemungkinan keinginan pelanggan untuk meningkatkan citra positif suatu produk (Hasan, 2014:121).

Berdasarkan definisi tersebut terlihat bahwa loyalitas lebih ditujukan kepada suatu perilaku yang ditunjukkan dengan pembelian rutin didasarkan pada unit pengambilan keputusan.

Jadi dapat disimpulkan bahwa loyalitas adalah komitmen pelanggan bertahan secara mendalam untuk berlangganan kembali atau melakukan pembelian ulang produk / jasa terpilih secara konsisten pada masa yang akan datang, 
meskipun pengaruh situasi dan usaha-usaha pemasaran mempunyai potensi untuk menyebabkan perubahan perilaku.

Faktor penentu kesetiaan pelanggan dengan cara menunjukkan bahwa peran utama loyalitas pelanggan dalam jangka panjang adalah (Hasan, 2014:126129):

a. Persepsi Value, dinyatakan sebagai perbandingan manfaat yang dirasakan dan biaya-biaya yang dikeluarkan pelanggan diperlukan sebagai faktor penentu kesetiaan pelanggan.

b. Kepercayaan, didefinisikan sebagai persepsi kepercayaan terhadap keandalan perusahaan yang ditentukan oleh konfirmasi sistematis tentang harapan terhadap tawaran perusahaan.

c. Relasional Pelanggan, didefinisikan sebagai persepsi pelanggan terhadap proporsionalitas rasio biaya dan manfaat, rasio biaya dan keuntungan dalam hubungan yang terus menerus dan timbal balik. Relasional pelanggan menjadi salah satu faktor penentu hubungan yang stabil dan tahan lama, dan itulah kesetiaan

d. Biaya Peralihan, merupakan salah satu dari faktor yang mempengaruhi kesetiaan. Peralihan pemasok melibatkan risiko waktu, uang, ketidakpastian dan usaha psikologis lainnya, oleh karena itu dalam kaitannya dengan pelanggan, switching cost ini menjadi faktor penahan/pengendali diri dari perpindahan pemasok/penyalur produk dan mungkin karenanya pelanggan menjadi setia.

e. Reliability, tidak hanya sebatas kemampuannnya menciptakan superior nilai bagi pelanggan, tetapi juga mencakup semua aspek capaian organisasi yang berkaitan apresiasi publik terhadap perusahaan secara langsung berdampak pada kesetiaan pelanggan.

\section{Kerangka Pemikiran}

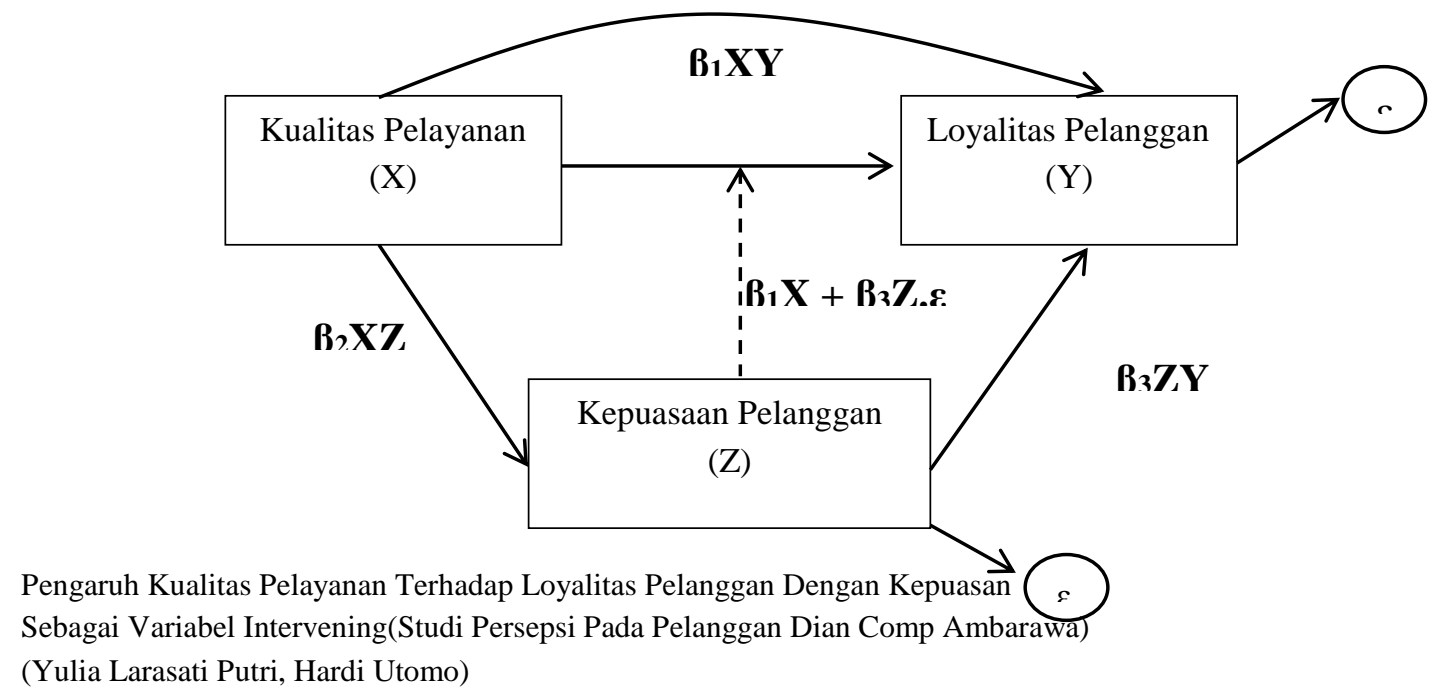




\section{Hipotesis}

1. Hipotesis I

Ho $\quad: \beta_{1} \mathrm{XY}=0 \quad$ (kualitas pelayanan tidak berpengaruh signifikan terhadap loyalitas pelanggan)

Ha $\quad: \beta_{1} X Y \neq 0 \quad$ (kualitas pelayanan berpengaruh signifikan terhadap loyalitas pelanggan)

2. Hipotesis II

Ho : $\beta_{2} \mathrm{XZ}=0$

(kualitas pelayanan tidak berpengaruh signifikan terhadap kepuasan pelanggan)

$\mathrm{Ha}: \beta_{2} \mathrm{XZ} \neq 0 \quad$ (kualitas pelayanan berpengaruh signifikan terhadap loyalitas pelanggan)

3. Hipotesis III

Ho $\quad \beta_{3} \mathrm{ZY}=0 \quad$ (kepuasaan pelanggan tidak berpengaruh signifikan terhadap loyalitas pelanggan)

Ha $\quad: \beta_{3} Z Y \neq 0 \quad$ (kepuasaan pelanggan berpengaruh signifikan terhadap loyalitas pelanggan)

4. Hipotesis IV

$\beta_{1} X Y<\beta_{1} X Z \times \beta_{3} Z Y$ (kualitas pelayanan berpengaruh signifikan terhadap loyalitas pelanggan dengan kepuasan pelanggan sebagai variabel intervening)

$\beta_{1} X Y>\beta_{1} X Z$ x $\beta_{3} Z Y \quad$ (kualitas pelayanan tidak berpengaruh signifikan terhadap loyalitas pelanggan dengan kepuasan pelanggan sebagai variabel intervening)

\section{METODE PENELITIAN}

1. Uji Instrumen

2. Uji Kelayakan Model

3. Analisisi Jalur (Path Analysis)

4. Pengujian Hipotesis $(\mathrm{Uji}-\mathrm{t})$

5. Pengujian Variabel Intervening : Pengaruh Langsung dan Tidak Langsung
: Uji Validitas dan Reliabilitas

: Koefisien Determinasi (Adjustmen R2)

\section{HASIL ANALISIS DATA}

\section{Pengujian Hipotesis dan Kelayanan Model}

\section{Hipotesis 1}

Hasil analisis regresi digunakan untuk menguji pengaruh kualitas pelayanan terhadap loyalitas pelanggan pada pelanggan Dian Comp disajikan pada tabel di bawah ini : 


\section{Tabel 1}

\section{Hasil Uji Analisis Jalur Kualitas Pelayanan (X) terhadap Loyalitas Pelanggan (Y)}

\begin{tabular}{|c|c|c|c|c|c|}
\hline \multicolumn{6}{|c|}{ Coefficients $^{a}$} \\
\hline \multirow[b]{2}{*}{ Model } & \multicolumn{2}{|c|}{ Unstandardized Coefficients } & \multirow{2}{*}{\begin{tabular}{|c|} 
Standardized Coefficients \\
Beta
\end{tabular}} & \multirow[b]{2}{*}{$\mathrm{t}$} & \multirow[b]{2}{*}{ Sig. } \\
\hline & $\mathrm{B}$ & Std. Error & & & \\
\hline 1 (Constant) & 5.637 & 1.440 & & 3.915 & .000 \\
\hline KUALITAS PELAYANAN (X) & .619 & .085 & .601 & 7.260 & .000 \\
\hline
\end{tabular}

Dari tabel diatas maka dapat dijabarkan sebagai berikut :

a. Persamaan Regresi

Dari hasil analisis regresi dapat diketahui persamaan regresi sebagai berikut :

$$
\begin{aligned}
& \mathrm{Y}=\beta_{1} \mathrm{X}+\mathrm{e}_{1} \\
& \mathrm{Y}=0,601 \mathrm{X}+0,799
\end{aligned}
$$

Dimana nilai 0,799 diperoleh dari rumus $\mathrm{e}_{1}=\sqrt{1-R^{2}}$

Tabel 2

Hasil Pengujian $\boldsymbol{R}^{2}$ Hipotesis 1 Model Summary ${ }^{b}$

\begin{tabular}{|l|r|r|r|r|}
\hline Model & $\mathrm{R}$ & $\mathrm{R}$ Square & \multicolumn{1}{|c|}{$\begin{array}{c}\text { Adjusted } \mathrm{R} \\
\text { Square }\end{array}$} & $\begin{array}{l}\text { Std. Error of the } \\
\text { Estimate }\end{array}$ \\
\hline 1 & $.601^{\mathrm{a}}$ & .362 & .355 & 1.484 \\
\hline
\end{tabular}

a. Predictors: (Constant), KUALITAS PELAYANAN (X)

b. Dependent Variable: LOYALITAS PELANGGAN (Y) Sumber : Pengolahan Data Primer

$$
\mathrm{e}_{1}=\sqrt{1-0,362}=\sqrt{0,638}=0,799
$$

dari persamaan diatas dapat dijelaskan :

1. Koefisien variabel kualitas pelayanan (X) adalah 0,601 dan bertanda positif artinya setiap perbaikan kualitas pelayanan satu satuan akan meningkatkan loyalitas pelanggan sebesar 0,601 satuan dengan asumsi variabel lainnya dianggap tetap.

2. $\mathrm{e}_{1}=$ jumlah variance loyalitas pelanggan $(\mathrm{Y})$ yang tidak dapat dijelaskan oleh variabel kualitas pelayanan (X) adalah sebesar 0,799. Artinya ada variabel lain yang memperngaruhi loyalitas pelanggan tersebut. 
b. Pengujian signifikansi regresi dengan uji $\mathrm{t}$

Uji hipotesis variabel kualitas pelayanan terhadap loyalitas pelanggan dilakukan dengan membandingkan $t_{\text {hitung }}$ yang diperoleh dari tabel 4.14, pada kolom $\mathrm{t}$ dengan $\mathrm{t}_{\text {tabel }}$ yang didapat dari distribusi $\mathrm{t}$. Apabila $\mathrm{t}_{\text {hitung }}>\mathrm{t}_{\text {tabel }}$, maka $\mathrm{H}_{0}$ ditolak.

Hasil statistik uji t untuk variabel kualitas pelayanan diperoleh nilai $\mathrm{t}$ hitung sebesar 7,260 dengan $t$ tabel sebesar 1,986 dan tingkat signifikansi 0,000, karena signifikansi lebih kecil dari $0,05(0,000<0,05)$, dan koefisien regresi mempunyai nilai positif sebesar 0,601 ; maka hipotesis yang menyatakan bahwa "Kualitas pelayanan berpengaruh signifikan terhadap loyalitas pelanggan", diterima. Berdasarkan hasil analisis tersebut itu membuktikan bahwa persepsi dari pelanggan atas kualitas pelayanan Dian Comp yang baik berpengaruh signifikan terhadap loyalitas pelanggan.

c. Koefisien Determinasi (Adjusted $\mathrm{R}^{2}$ )

Koefisien determinasi digunakan untuk melihat berapa persen variasi variabel terikat (Loyalitas Pelanggan) dapat diterangkan oleh variasi dari variabel bebas (Kualitas Pelayanan).

Tabel 3

Hasil Pengujian $\boldsymbol{R}^{2}$ Hipotesis 1 Model Summary ${ }^{\mathrm{b}}$

\begin{tabular}{l|r|r|r|r|}
\hline Model & $\mathrm{R}$ & $\mathrm{R}$ Square & $\begin{array}{c}\text { Adjusted R } \\
\text { Square }\end{array}$ & $\begin{array}{c}\text { Std. Error of the } \\
\text { Estimate }\end{array}$ \\
\hline 1 & $.601^{\mathrm{a}}$ & .362 & .355 & 1.484 \\
\hline
\end{tabular}
a. Predictors: (Constant), KUALITAS PELAYANAN (X)
b. Dependent Variable: LOYALITAS PELANGGAN (Y)

Nilai Adjusted $R$ Square hasil analisis data diperoleh sebesar 0,355. Hal ini berarti variasi variabel Kualitas Pelayanan (X) dapat menjelaskan variasi variabel Loyalitas Pelanggan (Y) sebesar 35,5\% dan sisanya 64,5\% dijelaskan oleh faktor lain yang tidak termasuk dalam penelitian ini, misalnya citra merek, harga dan lokasi.

\section{Hipotesis 2}

Hasil analisis regresi digunakan untuk menguji pengaruh kualitas pelayanan terhadap kepuasaan pelanggan pada pelanggan Dian Comp disajikan pada tabel di bawah ini : 


\section{Tabel 4}

Hasil Uji Regresi Kualitas Pelayanan (X)

terhadap Kepuasaan Pelanggan $(Z)$

Coefficients $^{\mathrm{a}}$

\begin{tabular}{|c|c|c|c|c|c|}
\hline \multirow[b]{2}{*}{ Model } & \multicolumn{2}{|c|}{$\begin{array}{c}\text { Unstandardized } \\
\text { Coefficients }\end{array}$} & \multirow{2}{*}{$\begin{array}{c}\begin{array}{c}\text { Standardized } \\
\text { Coefficients }\end{array} \\
\text { Beta }\end{array}$} & \multirow[b]{2}{*}{$\mathrm{t}$} & \multirow[b]{2}{*}{ Sig. } \\
\hline & $\mathrm{B}$ & Std. Error & & & \\
\hline $1 \quad$ (Constant) & 4.297 & 1.239 & & 3.469 & .001 \\
\hline $\begin{array}{l}\text { KUALITAS } \\
\text { PELAYANAN }(X)\end{array}$ & .710 & .073 & .708 & 9.679 & .000 \\
\hline
\end{tabular}

a. Dependent Variable: KEPUASAAN PELANGGAN (Z)

Dari tabel diatas maka dapat dijabarkan sebagai berikut :

(a) Persamaan Regresi

Dari hasil analisis regresi dapat diketahui persamaan regresi sebagai berikut :

$\mathrm{Z}=\beta_{2} \mathrm{X}$

$\mathrm{Z}=0,708 \mathrm{X}$

Persamaan regresi di atas menunjukkan bahwa koefisien variabel kualitas pelayanan (X) adalah 0,708 dan bertanda positif artinya setiap perbaikan kualitas pelayanan satu satuan akan meningkatkan kepuasaan pelanggan sebesar 0,708 satuan dengan asumsi variabel lainnya dianggap tetap.

(b) Pengujian signifikansi regresi dengan uji $\mathrm{t}$

Uji hipotesis variabel kualitas pelayanan terhadap kepuasan pelanggan dilakukan dengan membandingkan $t_{\text {hitung }}$ yang diperoleh dari tabel 4.16, pada kolom $\mathrm{t}$ dengan $\mathrm{t}_{\text {tabel }}$ yang didapat dari distribusi $\mathrm{t}$. Apabila $\mathrm{t}_{\text {hitung }}>\mathrm{t}_{\text {tabel }}$, maka $\mathrm{H}_{0}$ ditolak.

Hasil statistik uji t untuk variabel kualitas pelayanan diperoleh nilai t hitung sebesar 9,679 dengan t tabel sebesar 1,986 dan tingkat signifikansi 0,000, karena signifikansi lebih kecil dari $0,05(0,000<0,05)$, dan koefisien regresi mempunyai nilai positif sebesar 0,708 ; maka hipotesis yang menyatakan bahwa "Kualitas pelayanan berpengaruh signifikan terhadap kepuasaan pelanggan" diterima. Berdasarkan hasil analisis tersebut itu membuktikan bahwa pelanggan merasa puas atas pelayanan yang diberikan oleh Dian Comp sehingga persepsi dari pelanggan atas kualitas pelayanan Dian Comp yang baik berpengaruh signifikan terhadap kepuasan pelanggan.

(c) Koefisien Determinasi (Adjusted $\mathrm{R}^{2}$ )

Koefisien determinasi digunakan untuk melihat berapa persen variasi variabel intervening (Kepuasan Pelanggan) dapat diterangkan oleh variasi dari variabel bebas (Kualitas Pelayanan). 


\section{Tabel 5}

Hasil Uji $\boldsymbol{R}^{2}$ Hipotesis 2

Model Summaryb

\begin{tabular}{|l|r|r|r|r|}
\hline Model & $\mathrm{R}$ & $\mathrm{R}$ Square & \multicolumn{1}{c|}{$\begin{array}{c}\text { Adjusted R } \\
\text { Square }\end{array}$} & $\begin{array}{l}\text { Std. Error of the } \\
\text { Estimate }\end{array}$ \\
\hline 1 & $.708^{\mathrm{a}}$ & .502 & .496 & 1.277 \\
\hline
\end{tabular}

a. Predictors: (Constant), KUALITAS PELAYANAN (X)

b. Dependent Variable: KEPUASAAN PELANGGAN (Z)

Sumber : Pengolahan Data Primer

Nilai Adjusted $R$ Square hasil analisis data diperoleh sebesar 0,496. Hal ini berarti variasi variabel Kualitas Pelayanan (X) dapat menjelaskan variasi variabel Kepuasan Pelanggan (Z) sebesar 49,6\% dan sisanya 50,4\% dijelaskan oleh faktor lain yang tidak termasuk dalam penelitian ini.

\section{Hipotesis 3}

Hasil analisis regresi digunakan untuk menguji pengaruh kepuasan pelanggan terhadap loyalitas pelanggan Dian Comp disajikan pada tabel di bawah ini :

\section{Tabel 6}

\section{Hasil Uji Regresi Kepuasaan Pelanggan (Z)} terhadap Loyalitas Pelanggan (Y)

\section{Coefficients $^{\mathrm{a}}$}

\begin{tabular}{|c|c|c|c|c|c|}
\hline \multirow[b]{2}{*}{ Model } & \multicolumn{2}{|c|}{$\begin{array}{l}\text { Unstandardized } \\
\text { Coefficients }\end{array}$} & \multirow{2}{*}{$\begin{array}{c}\begin{array}{c}\text { Standardized } \\
\text { Coefficients }\end{array} \\
\text { Beta }\end{array}$} & \multirow[b]{2}{*}{$t$} & \multirow[b]{2}{*}{ Sig. } \\
\hline & $B$ & Std. Error & & & \\
\hline 1 (Constant) & 3,809 & 1,180 & & 3,227 & ,002 \\
\hline $\begin{array}{l}\text { KEPUASAAN PELANGGAN } \\
(\mathrm{Z})\end{array}$ & ,754 & ,072 & ,734 & 10,417 & ,000 \\
\hline
\end{tabular}

a. Dependent Variable: LOYALITAS PELANGGAN $(\mathrm{Y})$

Sumber : Pengolahan Data Primer

Dari tabel diatas maka dapat dijabarkan sebagai berikut :

(a) Persamaan Regresi

Dari hasil analisis regresi dapat diketahui persamaan regresi sebagai berikut :

$\mathrm{Y}=\beta_{3} \mathrm{Z}$

$\mathrm{Y}=0,734 \mathrm{Z}$

Persamaan regresi di atas menunjukkan bahwa koefisien variabel kepuasan pelanggan $(\mathrm{Z})$ adalah 0,734 dan bertanda positif artinya setiap peningkatan kepuasan pelanggan satu satuan akan meningkatkan loyalitas pelanggan sebesar 0,734 satuan dengan asumsi variabel lainnya dianggap tetap. 
(b) Pengujian signifikansi regresi dengan uji t

Uji hipotesis variabel kualitas pelayanan terhadap kepuasan pelanggan dilakukan dengan membandingkan $t_{\text {hitung }}$ yang diperoleh dari tabel 4.18, pada kolom $\mathrm{t}$ dengan $\mathrm{t}_{\text {tabel }}$ yang didapat dari distribusi $\mathrm{t}$. Apabila $\mathrm{t}_{\text {hitung }}>\mathrm{t}_{\text {tabel }}$, maka $\mathrm{H}_{0}$ ditolak. Hasil statistik uji t untuk variabel kepuasan pelanggan diperoleh nilai t hitung sebesar 10,417 dengan $\mathrm{t}$ tabel sebesar 1,986 dan tingkat signifikansi 0,000, karena signifikansi lebih kecil dari $0,05(0,000<0,05)$, dan koefisien regresi mempunyai nilai positif sebesar 0,734 ; maka hipotesis yang menyatakan bahwa "Kepuasan Pelanggan berpengaruh signifikan terhadap Loyalitas Pelanggan" diterima. Berdasarkan hasil analisis tersebut itu membuktikan bahwa pelanggan merasa puas atas pelayanan yang diberikan oleh Dian Comp sehingga akan menciptakan loyalitas dari pelanggan. Selain itu persepsi atas pelanggan loyal Dian Comp terbukti. Hal ini dapat dibuktikan dari kualitas pelayanan yang baik dan kepuasan yang diperoleh oleh pelanggan.

(c) Koefisien Determinasi (Adjusted $\mathrm{R}^{2}$ )

Koefisien determinasi digunakan untuk melihat berapa persen variasi variabel terikat (Loyalitas Pelanggan) dapat diterangkan oleh variasi dari variabel intervening (Kepuasan Pelanggan).

\section{Tabel 7}

\section{Hasil Uji $\boldsymbol{R}^{2}$ Hipotesis 3}

Model Summary

\begin{tabular}{|l|r|r|r|r|}
\hline Model & $\mathrm{R}$ & $\mathrm{R}$ Square & \multicolumn{1}{|c|}{$\begin{array}{c}\text { Adjusted R } \\
\text { Square }\end{array}$} & $\begin{array}{c}\text { Std. Error of the } \\
\text { Estimate }\end{array}$ \\
\hline 1 &, $734^{\mathrm{a}}$ &, 539 &, 534 & 1,262 \\
\hline
\end{tabular}

a. Predictors: (Constant), KEPUASAAN PELANGGAN (Z)

Sumber : Pengolahan Data Primer

Nilai Adjusted $R$ Square hasil analisis data diperoleh sebesar 0,534. Hal ini berarti variasi variabel Kepuasan Pelanggan (Z) dapat menjelaskan variasi variabel Loyalitas Pelanggan (Y) sebesar 53,4\% dan sisanya 46,6\% dijelaskan oleh faktor lain yang tidak termasuk dalam penelitian ini. 


\section{Pengujian Variabel Intervening (Pengaruh Langsung dan Tidak Langsung)}

Tabel 8

Hasil Uji Analisis Jalur Kualitas Pelayanan (X) terhadap Loyalitas Pelanggan (Y) dengan Kepuasan Pelanggan (Z) sebagai variabel intervening

\begin{tabular}{|c|c|c|c|c|c|}
\hline \multirow[b]{3}{*}{ Model } & \multicolumn{2}{|c|}{ Coefficients $^{a}$} & \multirow[b]{2}{*}{$\begin{array}{l}\text { Standardized } \\
\text { Coefficients }\end{array}$} & \multirow[b]{3}{*}{$\mathrm{t}$} & \multirow[b]{3}{*}{ Sig. } \\
\hline & \multicolumn{2}{|c|}{$\begin{array}{l}\text { Unstandardized } \\
\text { Coefficients }\end{array}$} & & & \\
\hline & B & Std. Error & Beta & & \\
\hline 1 (Constant) & 2.911 & 1.289 & & 2.258 & .026 \\
\hline KUALITAS PELAYANAN (X) & .168 & .102 & .16 & 1.656 & .101 \\
\hline $\begin{array}{l}\text { KEPUASAAN PELANGGAN } \\
\text { (Z) }\end{array}$ & .634 & .102 & .61 & 6.248 & .000 \\
\hline
\end{tabular}

a. Dependent Variable: LOYALITAS PELANGGAN (Y)

Sumber : Pengolahan Data Primer

Tabel 9

Hasil Uji $\boldsymbol{R}^{2}$ Hipotesis 4

Model Summary

\begin{tabular}{|l|c|r|r|r|}
\hline Model & $\mathrm{R}$ & $\mathrm{R}$ Square & Adjusted R Square & Std. Error of the Estimate \\
\hline 1 & $.743^{\mathrm{a}}$ & .552 & .542 & 1.250 \\
\hline
\end{tabular}

a. Predictors: (Constant), KEPUASAAN PELANGGAN (Z), KUALITAS

PELAYANAN $(X)$

b. Dependent Variable: LOYALITAS PELANGGAN (Y)

Sumber : Pengolahan Data Primer

Berdasarkan 2 tabel diatas diperoleh persamaan regresi sebagai berikut:

$\mathrm{Y}=\beta_{1} \mathrm{X}+\beta_{3} \mathrm{Z}+\mathrm{e}_{2}$

$Y=0,164 X+0,618 Z+0,669$

Nilai 0,669 diperoleh dari rumus $\mathrm{e}_{2}=\sqrt{1-R^{2}}$

$\mathrm{e}_{2}=\sqrt{1-0,552}=\sqrt{0,448}=0,669$

dari persamaan diatas dapat dijelaskan :

1. Koefisien variabel kualitas pelayanan (X) adalah 0,164 dan bertanda positif artinya setiap perbaikan kualitas pelayanan satu satuan akan meningkatkan loyalitas pelanggan sebesar 0,164 satuan dengan asumsi variabel lainnya dianggap tetap.

2. Koefisien variabel kepuasan pelanggan ( $\mathrm{Z}$ ) adalah 0,618 dan bertanda positif artinya setiap kenaikan kepuasaan pelanggan satu satuan akan meningkatkan loyalitas pelanggan sebesar 0,618 satuan dengan asumsi variabel lainnya dianggap tetap. 
3. $\mathrm{e}_{2}=$ jumlah variance loyalitas pelanggan $(\mathrm{Y})$ yang tidak dapat dijelaskan oleh variabel kualitas pelayanan $(\mathrm{X})$ dan Kepuasan Pelanggan $(\mathrm{Z})$ adalah sebesar 0,669. Artinya ada variabel lain yang memperngaruhi loyalitas pelanggan tersebut.

Dari hasil jalur path $\beta_{1} X Y=0,601$, nilai jalur path $\beta_{3} Z Y=0,734$, sehingga apabila dilihat dari bentuk gambar sebagai berikut :

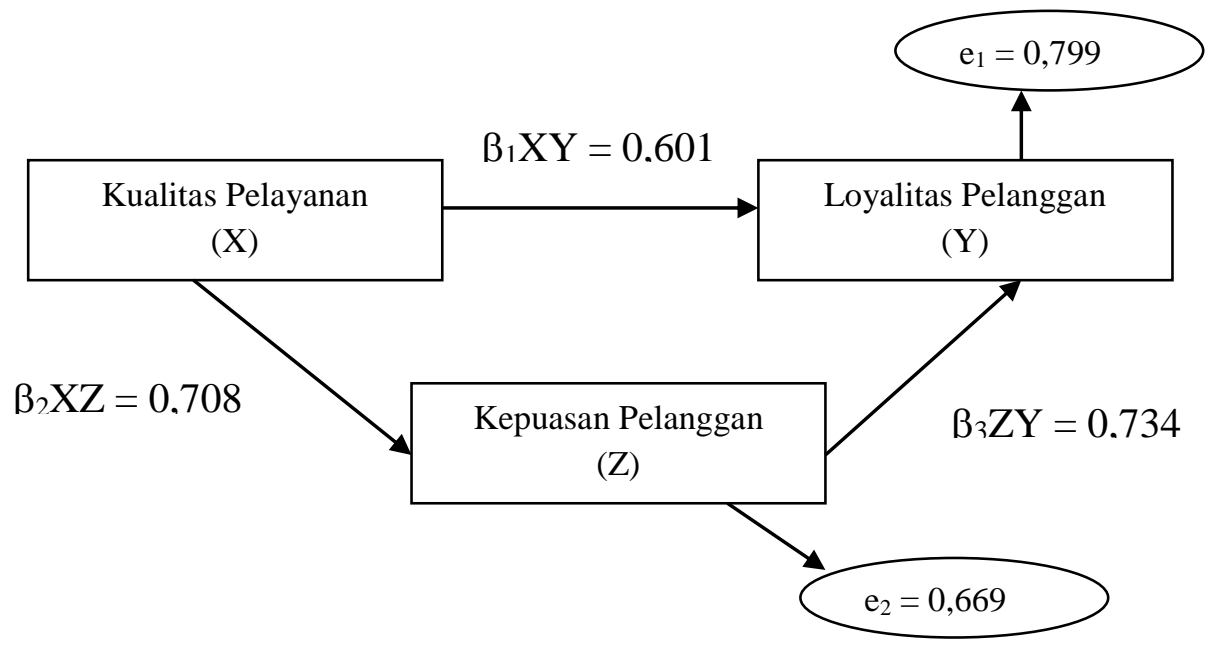

Gambar 2

Diagram Jalur Hipotesis 4

Hasil pengujian pengaruh langsung variabel kualitas pelayanan terhadap loyalitas pelanggan dan pengaruh tidak langsung variabel kualitas pelayanan terhadap loyalitas pelanggan dengan kepuasaan pelanggan sebagai variabel intervening dalam analisis jalur (path analysis) dapat diringkas sebagai berikut :

\section{Tabel 10}

Uji Perbandingan Pengaruh Langsung dan Pengaruh Tidak Langsung Variabel Kualitas Pelayanan Terhadap Loyalitas Pelanggan

\begin{tabular}{|c|c|c|c|}
\hline Variabel & $\begin{array}{c}\text { Pengaruh } \\
\text { Langsung (a) }\end{array}$ & $\begin{array}{c}\text { Pengaruh Tidak } \\
\text { Langsung (b) }\end{array}$ & Hasil \\
\hline Kualitas & 0,601 & $\begin{array}{c}0,708 \times 0,734= \\
0,519\end{array}$ & $\mathrm{a}>\mathrm{b}=\mathrm{H}_{0}$ Ditolak \\
\hline
\end{tabular}

Dengan membandingkan kedua hasil pada tabel 4.22 dapat ditarik kesimpulan bahwa nilai pengaruh tidak langsung < nilai pengaruh langsung, yaitu 0,519 $<0,601$ artinya tidak ada pengaruh signifikan antara variabel kualitas pelayanan terhadap 
loyalitas pelanggan dengan variabel intervening. Dengan demikian Hipotesis 4 yang menyatakan "Kualitas Pelayanan berpengaruh signifikan terhadap Loyalitas Pelanggan dengan Kepuasan sebagai variabel intervening” ditolak. Berdasarkan hasil di atas maka Kepuasan Pelanggan tidak memberikan pengaruh signifikan terhadap Loyalitas Pelanggan secara tidak langsung, dan Kualitas Pelayananlah yang secara langsung memberikan pengaruh terdapat Loyalitas Pelanggan. Hal ini diperkuat oleh hasil dari $\mathrm{t}$ hitung variabel intervening (Kepuasaan Pelanggan) $<\mathrm{t}$ hitung variabel eksgoen (Kualitas Pelayanan), yaitu 7,127 < 7,260. Hal ini berarti membuktikan bahwa Kepuasan Pelanggan bukan merupakan variabel intervening. Pada kenyataannya Pelanggan yang loyal adalah mereka yang menggunakan atau membeli ulang produk maupun yang sama, hanya mempertimbangkan usaha yang sama dan sama sekali tidak mencari informasi-informasi tentang usaha yang lain yang sejenis. Namun, sebelum perusahaan mencapai tahap kepuasan dan loyalitas pelanggan, perusahaan harus memperhatikan kualitas pelayanan. Kualitas pelayanan yang baik akan menciptakan kepuasan pelanggan yang pada akhirnya akan mencitakan loyalitas pelanggan.

Nilai Adjusted $R$ Square hasil analisis data diperoleh sebesar 0,542. Hal ini berarti variasi variabel Kualitas Pelayanan (X), dan Kepuasan Pelanggan (Z) dapat menjelaskan variasi variabel Loyalitas Pelanggan (Y) sebesar $54,2 \%$ dan sisanya $45,8 \%$ dijelaskan oleh faktor lain yang tidak termasuk dalam penelitian ini.

\section{SIMPULAN}

Tujuan penelitian yang telah dilakukan membahas tentang pengaruh kualitas pelayanan terhadap loyalitas pelanggan Dian Comp Ambarawa dengan kepuasan pelanggan sebagai variabel intervening. Berdasarkan analisis data yang telah dilakukan maka dapat ditarik beberapa kesimpulan sebagai berikut :

1. Pengujian Hipotesis 1

Setelah melakukan pengujian pada variabel kualitas pelayanan $(\mathrm{X})$ dan loyalitas pelanggan (Y) didapat persamaan regresi yaitu : $\mathrm{Y}=0,601 \mathrm{X}+0,799$. Dari persamaan di atas dapat dijelaskan bahwa nilai 0,601 merupakan nilai koefisien variabel kualitas pelayanan dan nilai 0,799 merupakan nilai error. Hal ini menjelaskan apabila kualitas pelayanan mengalami perbaikan atau peningkatan satu satuan, maka tingkat variabel loyalitas pada pelanggan Dian Comp akan meningkat sebesar 0,601 satu satuan dengan asumsi variabel yang lain dianggap tetap. Kualitas pelayanan berpengaruh positif terhadap loyalitas pelanggan. Hal ini dibuktikan dari nilai $\mathrm{t}$ hitung sebesar 7,260 dengan tingkat signifikansi $0,000<0,05$; dan koefisien regresi sebesar 0,601. Dengan Koefisien determinasi 
sebesar 0,355 artinya variabel kualitas pelayanan hanya dapat menjelaskan variabel Loyalitas Pelanggan sebesar 35,5\% sisanya 64,5\% di jelaskan oleh variabel lain yang tidak termasuk dalam penelitian ini. Berdasarkan uraian dan analisis data tersebut, terbukti bahwa Kualitas Pelayanan berpengaruh signifikan terhadap Loyalitas Pelanggan.

2. Pengujian Hipotesis 2

Pengujian pada variabel Kepuasan Pelanggan (Z) dan Loyalitas Pelanggan (Z). Kualitas pelayanan berpengaruh signifikan terhadap kepuasan pelanggan. Hal ini dibuktikan dari nilai $\mathrm{t}$ hitung sebesar 9,679 dengan tingkat signifikansi 0,000<0,05; dan koefisien regresi sebesar 0,708. Dengan Koefisien determinasi sebesar 0,496 artinya variabel Kualitas Pelayanan dapat menjelaskan variabel Kepuasan Pelanggan sebesar 49,6\%. Hal tersebut berarti Kualitas Pelayanan terbukti berpengaruh signifikan terhadap Kepuasan Pelanggan.

3. Pengujian Hipotesis 3

Pengujian pada variabel Kualitas Pelayanan (X) dan Kepuasan Pelanggan (Z). Kepuasan pelanggan berpengaruh signifikan terhadap loyalitas pelanggan. Hal ini dibuktikan dari nilai $\mathrm{t}$ hitung sebesar 10,417 dengan tingkat signifikansi $0,000<0,05$; dan koefisien regresi sebesar 0,734. Hal ini berarti Kualitas Pelayanan terbukti berpengaruh signifikan terhadap Kepuasan Pelanggan dengan koefisien determinasi sebesar 0,534 yaitu Kualitas Pelayanan dapat menjelaskan Loyalitas Pelanggan sebesar $53,4 \%$ sisanya dipengaruhi oleh variabel lain yang tidak dijelaskan dalam penelitian.

4. Pengujian Hipotesis 4

Hipotesis 4 yang menyatakan bahwa "Kualitas Pelayanan berpengaruh signifikan terhadap loyalitas pelanggan dengan kepuasan sebagai variabel intervening" dinyatak ditolak. Hal ini dibuktikan dari nilai pengaruh tidak langsung kualitas pelayanan terhadap loyalitas pelanggan < nilai langsung kualitas pelayanan terhadap loyalitas pelanggan, yaitu sebesar 0,519<0,601. Dengan demikian kualitas pelayanan memberikan kontribusi secara dalam mempengaruhi loyalitas pelanggan Dian Comp. Hal ini berarti membuktikan bahwa Kepuasan Pelanggan bukan merupakan variabel intervening pada penelitian ini

\section{SARAN}

Berdasarkan hasil penelitian, pembahasan dan kesimpulan yang diperoleh, maka saran yang dapat diberikan sebagai berikut :

1. Bagi Dian Comp

Pengaruh Kualitas Pelayanan Terhadap Loyalitas Pelanggan Dengan Kepuasan Sebagai Variabel Intervening(Studi Persepsi Pada Pelanggan Dian Comp Ambarawa) 
Berdasarkan hasil penelitian diketahui bahwa persepsi pelanggan pengguna jasa Dian Comp variabel kualitas pelayanan dengan indikator Assurance (Jaminan) mendapatkan skor terendah $(0,635)$. Oleh karena itu, dalam memberikan pelayanan mengenai estimasi waktu yang diberikan kepada pelanggan lebih ditingkatkan lagi, agar pelanggan tidak menunggu proses pengerjaan terlalu lama. Selain itu setelah barang selesai diproses dalam melakukan konfirmasi petugas lebih meningkatan dalam pelayanannya. Walaupun untuk pelayanan yang lain seperti bukti fisik (tangible) ruang tunggu yang nyaman, realibility kemampuan petugas dalam melayani pelanggan, responsiveness daya taggap petugas, empaty sudah baik bukan berarti diabaikan tetapi Dian Comp juga harus mempertahankan dan lebih meningkatkan dalam kualitas pelayanannya. Langkah ini diharapkan dapat lebih meningkatkan kepuasaan pelanggan sehingga menjaga loyalitas pelanggan sendiri di masa yang akan datang.

2. Peneliti Selanjutnya

Dari hasil penelitian koefisien determinasi Kualitas Pelayanan hanya sebesar 35,5\% artinya Kualitas Pelayanan kurang memberikan kontribusi terhadap loyalitas pelanggan. Peneliti selanjutnya dapat mengembangkan penelitian ini dengan meneliti faktor lain yang dapat mempengaruhi loyalitas pelanggan, misalnya faktor word of mouth, citra merek, dan kualitas produk. Selain itu, dikarenakan variabel kepuasan tidak terbukti mengintervening antara kualitas pelayanan terhadap loyalitas maka Peneliti selanjutnya juga dapat mengganti variabel intervening misalnya kepercayaan selain itu menggunakan metode lain dalam meneliti loyalitas konsumen, misalnya melalui wawancara mendalam terhadap pelanggan, sehingga informasi yang diperoleh dapat lebih bervariasi daripada angket yang jawabannya telah tersedia.

\section{DAFTAR PUSTAKA}

Alma, Buchari. 2005. Manajemen Pemasaran dan Pemasaran Jasa. Bandung: Alfabeta

Ariyani, F. 2008. Membangun Loyalitas Nasabah Melalui Peningkatan Kualitas Pelayanan dan Keunggulan Produk (Studi Empiris Pada PT. Bank Bukopin Tbk di Kota Semarang), Tesis, Magister Manajemen Universitas Diponegoro, Semarang.

Arikunto, Suharsimi.2010. Prosedur Penelitian Suatu Pendekatan Praktis. Jakarta, Rineka Cipta. 
Aris, Irnandha.2009. Pengaruh Kualitas Layanan Terhadap Loyalitas Pelanggan Yang Dimediasi Oleh Kepuasan Pelanggan Jasa Penggiriman Jalur Darat (Studi Kasus Kepuasan Pelanggan JNE Cabang Hijrah Sagan Yogyakarta), Yogyakarta : Manajemen UNY.

Kiki, Ega. (2009). Pengaruh Kualitas Pelayanan Terhadap Loyalitas Pelanggan dengan Kepuasan Sebagai Pemediasi (Studi Pada Pelanggan Pada Warung Spesial Sambal "SS" 4 Surakarta), Surakarta : Manajemen UNS.

Fandi Tjiptono. (2011). Kualitas Jasa: Pengukuran, Keterbatasan dan ImplikasiManajerial, majalah Manajemen Usahawan Indonesia. Jakarta.

Griffin R. W. 2005. Management Jilid 1. Jakarta: Erlangga.

Hasan, Ali. 2014. Marketing dan Kasus-kasus Pilihan, Cetakan Kedua. Yogyakarta. CAPS(Center for Academic Publishing Service).

Husein, Umar. 2005. Cetakan Pertama. Metode Riset Akuntansi Terapan. Jakarta: Ghalia Indonesia.

2013. Cetakan Keempat. Metode Riset Akuntansi Terapan. Jakarta: Ghalia Indonesia.

Imam Ghozali, 2001. Aplikasi Analisis Multivariate Dengan Program SPSS, Semarang: BP Undi.

Kotler, Philip dan Keller, Kevin Line. 2012. Edisi Bahasa Indonesia,Manajemen Pemasaran ,Jilid 1, Ed 12,PT Indeks.

Kusuma, Rizky Fajar. 2009. Analisis Pengaruh Kualitas Pelayanan Terhadap Loyalitas Pelanggan dengan Kepuasaan Pelanggan Variabel Pemediasi (Studi pada pelanggan Fixed-Wire Line Phone di Surakarta), Surakarta : Manajemen UNS.

Lupiyoadi, Rambat. 2001. Manajemen Pemasaran Jasa. Jakarta: Salemba Empat.

Parasuraman, A,.Valerie A. Zeithaml, and Leonard L. Berry,. 1988."SERVQUAL: A Multiple Item Scalefor measuring Consumer Perception of Service Quality.”Journal of Marketing, vol 64, p 12-40

Riduan dan Sunarto. 2007. Pengantar Statistika Untuk Penelitian : Pendidikan, Sosial, Komunikasi, Ekonomi dan Bisnis, Bandung : Alfabeta.

Tabel $\mathrm{r}$ dan tabel t diakses : http://junaidichaniago.wordpress.com/2010/ pada hari Rabu, 15 Februari 2017 pukul 9 : 21 PM.

Sinaga, Partua Pramana Hamonangan. 2010. Analisis Pengaruh Kualitas Pelayanan, Kepuasan Pelanggan, Dan Lokasi Terhadap Loyalitas Pelanggan ( Studi Kasus Pada Warnet Chamber Semarang ), Semarang : Manajemen UNDIP.

Sugiyono. 2010. Metode Penelitian Kuantitatif, Kualitatit dan R\&D, Bandung : Alfabeta.

Pengaruh Kualitas Pelayanan Terhadap Loyalitas Pelanggan Dengan Kepuasan

Sebagai Variabel Intervening(Studi Persepsi Pada Pelanggan Dian Comp Ambarawa)

(Yulia Larasati Putri, Hardi Utomo) 
2016. Metode Penelitian Kuantitatif, Kualitatit dan R\&D, Bandung : Alfabeta.

Sunyoto, Danang. 2012. Konsep Dasar Riset Pemasaran dan Perilaku Konsumen, Cetakan Pertama. Yogyakarta. CAPS(Center for Academic Publishing Service).

Tjiptono, Fandy. 2002. Strategi Pemasaran. Yogyakarta : Penerbit Andi.

2004. Strategi Pemasaran. Yogyakarta : Penerbit Andi.

.2006. Strategi Pemasaran. Yogyakarta : Penerbit Andi.

2007. Strategi Pemasaran. Yogyakarta : Penerbit Andi.

Tjiptono, Fandy dan Chandra, Gregorius. 2011. Service, Quality, and Satisfaction. edisi pertama. Yogyakarta : Andi Offset.

Wibowo, Endro. 2016. Pengaruh Keselamatan Kerja dan Kesehatan Kerja

Terhadap Kinerja Dengan Kepuasaan Kerja Sebagai Variabel Intervening (Studi Kasus pada Karyawan Bagian Produksi Unit Serbuk Effervescent PT Sido Muncul Semarang), Salatiga : Manajamen STIE AMA. 